短 報 Japanese Journal of Health Promotion and Physical Therapy Vol. 11, No. 2: 73-77, 2021

\title{
体幹の変化が足趾把持力に及ぼす影響 Effect of trunk posture on toe grip strength
}

\author{
相馬 正之 ${ }^{1)}$, 村田 伸 ${ }^{2}$, 甲斐 義浩 ${ }^{2}$

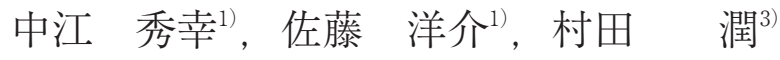 \\ Masayuki Soma ${ }^{1)}$, Shin Murata ${ }^{2)}$, Yoshihiro Kai ${ }^{2)}$ \\ Hideyuki Nakae ${ }^{1)}$, Yousuke Satou ${ }^{1}$, Jun Murata
}

\begin{abstract}
要旨：[目的］本研究では，体幹垂直位と体幹前傾位で測定した足趾把持力と下肢の筋活 動量を比較し，体幹の肢位変化が足趾把持力に及ほすす影響を明らかにするため，測定値の 再現性㧍よび最大筋力の発揮の観点から検討した。[対象・方法］健常成人男性18名を対 象とした。足趾把持力の測定は，体幹垂直位と体幹前傾位の 2 条件で行った。測定項目は, 足趾把持力および足趾把持力発揮時の大腿直筋と大腿二頭筋長頭, 前脛骨筋, 腓腹筋内側 頭の筋活動量とした。[結果] 分析の結果, 級内相関係数（1，1）は, 体幹垂直位が $\mathrm{r}$ $=0.921$, 体幹前傾位が $\mathrm{r}=0.950$ であった。足趾把持力は 2 条件間には有意差を認めな かったものの，体幹垂直位に打ける腓腹筋内側頭の％IEMG は体幹前傾位より有意に高值 を示した。[結語] 本研究結果から, 体幹垂直位と体幹前傾位による体幹変化は, 足趾把 持力の再現性や最大筋力に影響を及ぼさないものの，腓腹筋内側頭の\%IEMGに影響を及 ぼすことが示された。
\end{abstract}

キーワード：足趾把持力, 測定肢位, 体幹肢位

\begin{abstract}
Purpose] This study aimed to clarify the effect of changes in trunk-leg posture on toe grip strength by comparing the toe grip strength and lower extremity muscle activity measured during upright and forward-tilted trunk postures and investigating these values in terms of reproducibility and exertion of the maximum muscle strength. [Subjects and methods] The study subjects were 18 healthy adult males. Toe grip strength was measured under two conditions: in the upright trunk posture and the anteriorly tilted trunk posture. In addition to toe grip strength, muscle activity of the rectus femoris, the long head of the biceps femoris, the anterior tibialis, and the medial head of the gastrocnemius were also measured. [Results] The results showed internal correlation coefficients (1, 1) of $r=0.921$ and $r=0.950$ for the upright and anteriorly tilted trunk postures, respectively. Although the toe grip strength did not differ between the two measurement conditions, the percentage integrated electromyography (\%IEMG) of the medial head of the gastrocnemius was significantly higher in the upright posture than that in the anteriorly tilted posture. [Conclusion] The results of this study showed that the different trunk posturesupright and anteriorly tilted-did not affect the reproducibility or the maximum muscle force of toe grip strength but did affect the \%IEMG of the medial head of the gastrocnemius.
\end{abstract}

Key words: toe-grip strength, Measurement position, trunk posture

受付日：2021年 1月21日，採択日：2021年 3 月 3 日

1) 東北福祉大学健康科学部：干981-8522 宮城県仙台市青葉区国見 1-8 - 1 Tel：022-233-3111 FAX：022-233-3113 Faculty of Health Sciences, Tohoku Fukushi University: 1-8-1, Kunimi, Aoba-ku, Sendai-city, 981-8522, Japan Tel: 022-233-3111 FAX: 022-233-3113

E-mail :souma@tfu-mail.tfu.ac.jp

2) 京都橘大学健康科学部

Faculty of Health Science, Kyoto Tachibana University

3) 長崎大学大学院 医歯薬学総合研究科保健学専攻

Department of Health Sciences, Graduate School of Biomedical Sciences, Nagasaki University 


\section{I 、はじめに}

理学療法において下肢の筋力評価は, 対象者の機能 評価として必須項目である。とくに, 定量化できる Hand held dynamometer (以下, HHD) ${ }^{1,2}$ は, 臨床 や研究の場で広く用いられている。なかでも等尺性膝 伸展筋力は, $\mathrm{ADL}^{3)}$ や歩行能力 ${ }^{4)}$ 影響を与えること が示されており，重要な下肢筋力の指標となっている。 また，等尺性伸展筋力については，測定方法の信頼性 といった検討 ${ }^{5-8)}$ が多く行われてきた。例えば，HHD 測定時の固定ベルトの使用の有無では, 固定用ベルト を用いる条件の信頼性が高くなる5)ことが示されてい る。また，測定時に非測定側の下肢を床に接地する条 件は非接地条件より ${ }^{6)}$, 手指でベッド端を把持する条 件は把持しない条件より ${ }^{7}$ 測定值が大きいことが報告 されている。他にも，異なる座位姿勢が測定值に与え る影響などの検討 ${ }^{8)}$ が行われてきた。膝関節伸展筋力 の測定方法は，これらの先行研究を踏まえ，測定肢位 やベルト固定法などが詳細に規定されている9

近年, バランス機能や歩行機能, 転倒リスクとの間 に関連が示されている足趾把持力が注目されてい $る^{10-12)}$ 。しかし, 足趾把持力の測定方法については, 十分な検討がされていない。現在, 足趾把持力の測定 は，端座位，股および膝関節を90度屈曲し，足関節底 背屈中間位で行われることが多い ${ }^{10-12)}$ 。測定肢位を検 討した先行研究では，足関節は背屈位および中間位が 底屈位よりも最大発揮しやすいことが示されている ${ }^{13)}$ また, 膝関節伸展位では膝関節90度屈曲位よりも最大

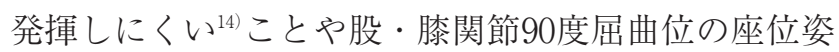
勢が立位姿勢と同等の足趾把持力を発揮できることが 報告 ${ }^{15)}$ されている。これらのことから，姿勢や下肢の 肢位は現行法が適していることが示唆されるが, 体幹 の肢位については未だ検討されていない。

実際の測定場面において，筆者らは足指把持測定器 に表示される值に興味を示しながら力を発揮する人, つまり体幹前傾位となる人に対して, 体幹垂直となる ように口頭指示を与えて測定を行っている。しかし， この方法が正しいかどうかは不明であり，検討がなさ れていない。体幹前傾位および体幹垂直位の肢位の相 違は, 主として頸胸腰椎の屈曲, 伸展と骨盤の前・後 傾であることが推測できる。したがって，この体幹の 肢位変化が足趾把持力に及ぼす影響を明らかにするこ とは，適切な足趾把持力の測定肢位を検討するために も重要と思われる。

そこで本研究は, 体幹垂直位および体幹前傾位で測
定した足趾把持力や下肢の筋活動量を比較し，体幹の 肢位変化が足趾把持力に及ぼす影響について，測定值 の再現性および最大筋力の発揮の観点から検討した。

\section{II. 対象・方法}

\section{1. 対 象}

対象は，健常成人男性18名とした。いずれも下肢に 整形外科的疾患や疼痛などの既往はなかった。対象者 の年齢は平均 $20.8 \pm 0.8$ 歳, 身長は平均 $173.0 \pm 4.9 \mathrm{~cm}$, 体重は平均 $64.6 \pm 6.5 \mathrm{~kg}$ であった。対象者には研究の 趣旨と内容, 得られたデー夕は研究の目的以外には使 用しないこと，および個人情報の漏洩に注意すること について説明し，十分に理解を得たうえで協力を求め た。また, 研究への参加は自由意志であり, 被験者に ならなくても不利益にならないことを口答と書面で説 明し，同意を得て研究を開始した。なお，本研究は， 所属機関の研究倫理委員会の承認（RS160706）を受 けて実施した。

\section{2. 方 法}

測定項目は, 利き脚の足趾把持力と表面筋電困 (Electromyogram：以下, EMG) から得られる足趾 把持力発揮時の大腿直筋と大腿二頭筋長頭，前脛骨筋， 腓腹筋内側頭の筋活動量とし，それぞれを同期させ測 定した。本研究では利き脚の定義を，ボールを蹴る脚 とし，対象者のすべてが右脚であった。

足趾把持力の測定には, 足指把持力測定器 (竹井機 器工業社製，T.K.K. 3362）を用いた。測定肢位は, 端座位で両腕を組ませ，股および膝関節を90度屈曲， 足関節底背屈中間位とし, 足関節固定ベルトを使用し た。体幹肢位は，前方を注視させる体幹垂直位と床面 に置いた足指把持力測定器から $10 \mathrm{~cm}$ 前方を注視させ

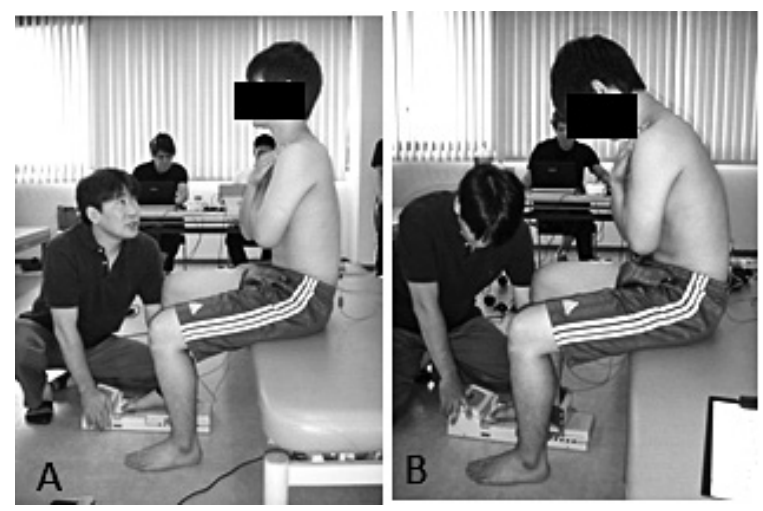

図 12 条件の体幹肢位について

A：体幹垂直位

B：体幹前傾位 
る体幹前傾位の 2 条件とした（図 1 )。足趾把持力の 測定は, 十分に練習させた後, 休息を設けながら各条 件 2 回ずつ, 合計 4 回, 測定した。また, 課題遂行の 順序による影響を相殺するために，対象者毎に測定順 をランダムに測定した。

被験筋は, 足関節周囲筋の表面筋電図で導出可能で ある，大腿直筋，大腿二頭筋長頭，前脛骨筋および腓 腹筋内側頭の 4 筋とし, 足趾把持力測定時の筋活動量 を測定した。表面筋電図の測定は双極誘導法で行い, 電極はプリアンプ内臓パラレルバー電極 $\mathrm{DE}-2.1$

(Delsys 社製) を用い, 皮膚処理を十分（皮膚抵抗 $5 \mathrm{k} \Omega$ 以下）に行った上で, Perottoの記述 ${ }^{16)} に$ 準じ, 電極間距離は $2 \mathrm{~cm}$ とし貼付した。計測された表面筋 電図信号は, デー夕収集・解析システム ML846PowerLab 4/26（ADInstrument 社製）を用い，サンプリ ング周波数 $1,000 \mathrm{~Hz}$ にて $\mathrm{A} / \mathrm{D}$ 変換を行い，帯域幅を 20-500Hz としてパーソナルコンピュータに取り込ん だ。

4 つの被験筋である大腿直筋，大腿二頭筋長頭およ び前脛骨筋, 腓腹筋内側頭の最大随意等尺性収縮 (maximum voluntary contraction : MVC) の筋活動 量は，座位にて測定した。足趾把持力測定時の表面筋 電図は，随意収縮力発揮のピークを中心とする 3 秒間 において，前後 1 秒間分を除いた中間 1 秒間の積分筋 電図 (Integrated Electromyogram; 以下, IEMG) を解析対象とした。

表面筋電図の解析には, 測定・解析ソフトウェア LabChart Pro v7. 3.5（AD Instruments 社製）を使用 し, 得られたIEMGは各筋の端座位における MVC
時の測定値を基準に正規化（\%IEMG）した。

統計処理は，足趾把持力の再現性には級内相関係数 （1，1）を求めた。また，体幹垂直位および体幹前 傾位における足趾把持力と足趾把持力発揮時の大腿直 筋，大腿二頭筋長頭，前脛骨筋と腓腹筋内側頭の $\%$ IEMG の比較には，2 回測定の最大值を代表值として 対応のある $\mathrm{t}$ 検定を用いた。その後, 測定值の平均と 標準偏差から効果量（Cohen's d) を求めた。Cohen's $\mathrm{d}$ に抢ける数值の解釈 ${ }^{17}$ は, 小さい>0.20, 中程度> 0.50，大きい>0.80とした。

\section{III. 結 果}

被験者18名の級内相関係数（1，1）は，体幹垂直 位が $\mathrm{r}=0.921$ ，体幹前傾位が $\mathrm{r}=0.950$ であった（表 1 )。表 2 に示す。足趾把持力は有意な差を認めなかっ たものの，体幹垂直位における腓腹筋内側頭の\% IEMG は体幹前傾位より有意に高值を示した。一方, 大腿直筋，大腿二頭筋長頭，前脛骨筋の $\%$ IEMG につ いては, 有意な差が認められなかった。有意差が認め られた腓腹筋内側頭の\%IEMGの効果量は, $\mathrm{d}=0.20$ であった。

\section{IV. 考 察}

本研究では，体幹の肢位変化が足趾把持力に及ぼす 影響について再現性および最大筋力発揮の観点から検 討した。分析の結果，体幹肢位 2 条件間の足趾把持力 には有意な差を認めなかった。しかし，体幹垂直位に おける腓腹筋内側頭の\%IEMGは体幹前傾位より有意 に高值を示した。これらのことから，体幹垂直位およ

表 1 足趾把持力における級内相関係数 $(n=18)$

\begin{tabular}{ccc}
\hline & 体幹垂直位 & 体幹前傾位 \\
\hline 1 回目 $(\mathrm{kg})$ & $26.9 \pm 6.0$ & $27.7 \pm 4.9$ \\
2 回目 $(\mathrm{kg})$ & $27.1 \pm 4.8$ & $28.1 \pm 5.1$ \\
級内相関係数 & $0.921(0.805-0.969)$ & $0.950(0.873-0.981)$ \\
$(95 \%$ 信頼区間 $)$ & & \\
\hline (平均值 標準偏差 $)$ & &
\end{tabular}

(平均值 \pm 標準偏差)

表 2 体幹垂直位と体幹前傾位における足趾把持力と各筋の\%IEMG（ $\mathrm{n}=18 ）$

\begin{tabular}{lrrrrrr}
\hline & \multicolumn{2}{c}{ 体幹垂直位 } & \multicolumn{2}{c}{ 体幹前傾位 } & \multirow{2}{*}{ 值 } & \multirow{2}{*}{ 効果量 } \\
& 平均 & 標準偏差 & 平均 & 標準偏差 & & \\
\hline 足趾把持力 $(\mathrm{kg})$ & 27.83 & 5.28 & 28.59 & 5.10 & 0.14 & 0.02 \\
大腿直筋 (\%IEMG) & 2.25 & 1.53 & 2.10 & 1.31 & 0.26 & 0.01 \\
大腿二頭筋長頭 (\%IEMG) & 11.70 & 11.83 & 8.90 & 6.35 & 0.20 & 0.03 \\
前脛骨筋 (\%IEMG) & 33.82 & 24.88 & 31.14 & 19.14 & 0.23 & 0.12 \\
腓腹筋内側頭 (\%IEMG) & 37.46 & 16.94 & 33.99 & 17.22 & 0.03 & 0.20 \\
\hline
\end{tabular}


び体幹前傾位による体幹の変化は，足趾把持力の再現 性や最大筋力に影響を及ぼさないものの, 腓腹筋内側 頭の\%IEMGに影響を及ぼすことが示された。

本研究で得られた足趾把持力は，26.9〜28.6kg で あった。先行研究に打ける同年代の健常成人男性の足

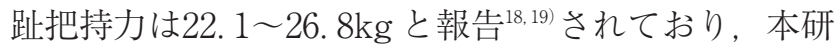
究の健常成人男性はやや高い筋力レベルの集団であっ たと考えられる。

本結果から体幹肢位の変化は, 腓腹筋内側頭の $\%$ IEMG に影響を及ぼすことが示された。体幹垂直位は， 体幹前傾位に比べ重心位置が後方に偏位するため, 足 部への荷重量が減少する。強い足趾把持力発揮には, 足関節を構成する距腿関節の安定性が影響することが

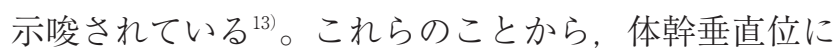
おける腓腹筋内側頭の筋活動量の増加は, 足関節の荷 重量の減少に伴う足関節の安定性を補うため, 代償的 に生じたことが考えられた。しかし, 平均值の差を標 準化した効果量を算出すると，小さい効果量となった。 よって今回, 対象とした男性では, 体幹肢位の変化に より，腓腹筋内側頭の筋活動量の影響を受けるものの， 影響の程度は小さいことが確認された。

本研究から体幹垂直位および体幹前傾位の 2 条件で 測定した足趾把持力に有意な差を認めなかったことか ら，体幹の肢位変化は足趾把持力に影響を及ぼさない ことが示された。足趾把持力発揮時には足関節や膝関 節の安定化作用のために下腿部や大腿部の筋肉が同時 収縮することが報告されている ${ }^{20,21)}$ 。しかし，足趾か ら遠位である体幹の肢位変化は，足趾把持力に影響を 及ぼさないことが推測された。

本結果から体幹垂直位と体幹前傾位の体幹の肢位変 化は，腓腹筋内側頭の\%IEMG に影響を及ぼすものの， 足趾把持力の最大筋力発揮や再現性には影響を及ほさ ないことが示された。足趾把持力は，高齢者における 体力測定会などで測定されることが多い22.23)。そのた め，骨盤後傾位，円背を呈している高齢者に対して足 趾把持力を測定する際は, 体幹肢位を厳密に規定しな くてもよいと考えられた。

\section{引用文献}

1) Hirano M, Gomi M, Katoh M:Effect of trunk stability on isometric knee extension muscle strength measurement while sitting. J phys Ther Sci, 2016, 28(9): 2474-2476.

2)村田伸, 忽那龍雄 : 在宅障害高齢者に対する転倒予防対策 - 足把持力トレーニング. 日本在宅ケア学会誌, 2004, 7 (2) : 67-74.
3) Ringsberg K, Gerdhem P, Johansson J,et al.:Is there relationship between balance, gait performance and muscular strength in 75-year-old women?. Age Ageing, 1999, 28(3): 289 -293 .

4) 浅川康吉, 池添冬芽, 羽崎完・他：高齢者における下肢筋 力と起居 - 移動動作能力の関連性. 理学療法学, 1997, 24 (4) : 248-253.

5)山崎裕司, 長谷川輝美: 固定用ベルトを装着したダイナモ メーターによる等尺性膝伸展筋力の測定－検者内再現性の 検討 - 。高知リハビリテション学院紀要, 2002, 3 ：7-11.

6) 山崎裕司, 有澤亜弥, 大倉三洋 ・他：固定用ベルトを使用 した等尺性膝伸展筋力測定方法の検討 - 試行回数と非測定 側下肢支持の影響一. 高知リハビリテション学院紀要, 2010, $11: 31-34$.

7)高木亮輔, 平野正広, 柊幸伸・他：ハンドヘルドダイナモ メーターを用いた等尺性膝伸展筋力測定における骨盤固定 が測定值に及ぼす影響. 了徳寺大学研究紀要, 2016, 10 : 175-182.

8)栗山裕司, 山裕司, 坂上昇・他：固定用ベルトを装着した ハンドヘルドダイナモメーターによる等尺性膝伸展筋力の 測定一異なる座位姿勢間における再現性の検討一。高知リ ハビリテション学院紀要, 2003, 4: 1-6.

9)片山訓博, 山崎裕司：筋力の測定. Jpn Rehabili Med, 2017, 54(10): 761-763.

10)村田伸, 忽那龍雄 : 在宅障害高齢者の足把持力と転倒との 関連性. 国立大学理学療法士学会誌, 2003, 24：8-13.

11) 新井智之, 藤田博暁, 細井俊希 ·他 : 地域在住高齢者にお ける足趾把持力と年齢, 性別および運動機能との関連. 理 学療法学, 2011, 38(7) : 489-496.

12)相馬正之, 五十嵐健文, 工藤渉・他：若年者における足指 把持力と歩行能力の関係について. 東北理学療法学, 2012, $24: 54-58$.

13)相馬正之, 村田伸, 甲斐義浩・他：足関節の角度変化によ る足指把持力の比較.ヘルスプロモーション理学療法研究, 2013, 3 (1) : 21-23.

14) Soma M, Murata S,Kai $Y$, et al.:An examination of limb position for measuring toe-grip strength. J Phys Ther Sci, 2014, 26(12): 1955-1957.

15) 中江秀幸, 村田伸, 甲斐義浩・他：端座位と立位における 足趾把持力と足関節周囲筋の筋活動の比較.ヘルスプロモー ション理学療法研究, 2013, 3 (1) : 11-14.

16) Aldo O. Perotto : 筋電図のための解剖ガイドー四肢・体幹 一第 3 版． 西村書店，東京，2007，140-155.

17) 水本篤, 竹内理 : 効果量と検定力分析入門 (統計的検定を 正しく使うために)。外国語教育メディア学会（LET）関 西支部メソドロジー研究部会2010年度報告論集，2010，4773.

18) 原丈貴：日常生活における疑似的な裸足歩行がバランス機 能および歩行能力に及ぼす影響. デサントスポーツ科学, 2018, 39 : 234-240.

19) 山田健二, 須藤明治：足把持運動における足部筋活動との 関係. 理学療法科学, 2018, 33(1) : 183-186.

20)相馬正之, 村田伸, 甲斐義浩 - 他 : 足趾把持力発揮時にお ける下腿筋の筋活動. 理学療法科学, 2013, 28(4)：491-494. 
21)Soma M, Murata S, Kai Y, et al.: Activity of the femoral muscles during toe-gripping action. J. Phys. Ther. Sci 26 (10), 2014: 1619-1621.

22) Uritani D, Fukumoto T, Matsumoto D: Associations between toe grip strength and hallux valgus, toe curl ability, and foot arch height in Japanese adults aged 20 to 79 years: a cross-sectional study. J Foot Ankle Res, 2015, 8: 18

23)二階堂素子, 安彦鉄平, 阿南邦彦 ·他 : 地域在住の前期高 齢女性と後期高齢女性の握力および足趾把持力が身体機能 に及ぼす影響について、ヘルスプロモーション理学療法研 究, 2016, $6(2): 53-57$. 